\title{
DAMPAK PENAMBANGAN PASIR DI KAWASAN PEGUNUNGAN PERSPEKTIF TRI HITA KARANA
}

Oleh :

I Komang Suastika Arimbawa

\begin{abstract}
Sand is one of the supporting resources in the development sector, both physically, economically and socially. The need for sand in the construction industry sector has increased along with the development of infrastructure and facilities. In addition to bringing huge benefits, sand mining in mountainous regions can also cause environmental impacts such as landslides, erosion, pollution, and so on. The environmental impacts of sand mining activities in mountainous regions are divided into two, namely physical impacts and socio-economic impacts. Socio-economic impacts such as increasing community income, reducing the number of unemployed people, opening jobs, income for landowners who are sold or leased to take sand at high prices, many migrants join in mining so that it can lead to conflict, there is fear in some communities because of sand mining landslide potential.

The view in the teachings of Hinduism about environmental damage that occurs is not only related to environmental problems but also concerns the problem of God values embodied in environmental preservation. Therefore, the existence of human resources becomes a determinant of environmental conditions, both individually and collectively. For this reason, it is necessary to have a balanced life patterned in the teachings of Tri Hita Karana. The philosophy of life in Tri Hita Karana is to create a balanced and consistent attitude to believe and devotion to God, serve others and maintain the welfare of the natural environment. Understanding of Tri Hita Karana should not be fragmented because it should be understood as Tri Hita Karana as a whole, synergistic and consistent as a universal philosophy of life.
\end{abstract}

Keywords: environmental damage, sand mining, Tri Hita Karana.

\section{PENDAHULUAN}

Bukti ketergantungan manusia kepada alam dapat dilihat dari pemanfaatan sumber daya alam yang besar-besaran tanpa melihat kelanjutan fungsinya. Dewasa ini, setiap daerah saling berlomba-lomba untuk memanfaatkan kekayaan alam masing-masing. Salah satu kegiatan pemanfaatan sumber daya alam yang dapat "mengundang" pendapatan besar bagi suatu wilayah adalah penambangan pasir. Pasir merupakan salah satu sumber daya pendukung pada sektor pembangunan, baik secara fisik, ekonomi maupun sosial. Kebutuhan akan pasir pada sektor industri konstruksi semakin meningkat seiring dengan berkembangnya pembangunan sarana dan prasarana.

Penambangan pasir, selain mendatangkan keuntungan yang cukup besar juga rawan terhadap terjadinya perusakan lingkungan apabila tidak dikelola dengan baik dan benar. Dengan kata lain, setiap kegiatan penambangan tentu akan menimbulkan dampak baik maupun 
buruk. Gambaran tentang kondisi dimasa yang akan datang bahwa keberadaan sumber daya alam akan menjadi semakin terbatas, yang akan berakibat pada menurunnya daya dukung lingkungan sebagai akibat daripada semakin bertambahnya penduduk, pergeseran pola hidup dan dampak dari kegiatan pembangunan. Adanya fenomena yang menunjukan bahwa upaya manusia memanfaatkan sumber daya dengan cara yang tidak bijaksana, menyebabkan kondisi sumber daya menjadi rawan dan menjadi ancaman bagi kehidupan manusia, misalnya banjir, tanah longsor, erosi, polusi, dan sebagainya (Soemarwoto, 2003).

Pandangan dalam ajaran agama Hindu mengenai kerusakan lingkungan yang terjadi tidak hanya menyangkut masalah lingkungan hidup melainkan menyangkut masalah nilai-nilai Ketuhanan yang diwujudkan pada pelestarian lingkungan. Umat Hindu meyakini bahwa segala yang ada pada lingkungan, baik itu yang hidup seperti tumbuhan dan hewan maupun yang tidak hidup seperti benda-benda mati adalah ciptaan Tuhan. Tumbuhan dan hewan sebagai sistem ekologi sama halnya dengan manusia yang memiliki energi 'Ilahi' yang disebut dengan Atman.

Oleh karena itu, keberadaan sumber daya manusia menjadi penentu terhadap kondisi lingkungan hidupnya, baik secara individu maupun secara kolektif. Untuk itulah perlu adanya kesimbangan hidup yang terpola dalam ajaran Tri Hita Karana. Tri Hita Karana merupakan tiga penyebab keharmonisan, yaitu hubungan yang harmonis antara manusia dengan Tuhan, manusia dengan sesama dan manusia dengan lingkungannya. Konsep yang lain seperti Tat Tvam Asi dan Vasudaiva Kutumbhakam yang memiliki arti bahwa segala yang ada adalah sama atau bersaudara. Konsep ini begitu popular dalam percakapan umat Hindu, khususnya di Bali. Menurut Wiana (2004), hakekat Tri Hita Karana adalah sikap hidup yang seimbang antara memuja Tuhan dengan mengabdi pada sesama manusia serta mengembangkan kasih sayang pada alam lingkungan. Ajaran tentang keseimbangan hidup sangat penting artinya dalam kehidupan manusia, baik untuk menata kehidupan sekarang maupun untuk menata kehidupan yang akan datang. Ajaran keseimbangan hidup menuntun manusia agar memperoleh kehidupan yang aman, damai dan sejahtera.

Setia (2006) menjelaskan bahwa umat Hindu sudah melaksanakan ajaran Tri Hita Karana, tetapi apa yang telah dilaksanakan belum sesuai dengan konsepnya, atau sudah melaksanakan tetapi hanya sebagian kecil saja, sementara yang dilanggar justru lebih banyak. Pelanggaran yang paling parah adalah pada unsur palemahan-nya yaitu yang menyangkut hubungan manusia dengan alam lingkungannya. Berdasarkan konsep yang diajarkan dalam agama Hindu maka aktivitas manusia yang berdampak pada kerusakan lingkungan demi kepentingan pihak-pihak tertentu sesungguhnya sangat bertentangan dengan ajaran agama.

\section{PEMBAHASAN}

Kegiatan penambangan pasir dikenal 
sebagai suatu kegiatan yang dapat 'merubah' struktur permukaan bumi. Oleh karena itu, kegiatan penambangan sering dikaitkan dengan kerusakan lingkungan. Walaupun pernyataan tersebuttidaksepenuhnyabenar,namunjugapatut diakui bahwa banyak kegiatan penambangan yang mengakibatkan kerusakan pada wilayah di mana penambangan tersebut dilakukan. Akan tetapi di lain pihak, kualitas lingkungan di tempat penambangan tersebut akan meningkat secara drastis, termasuk juga kualitas hidup manusia yang berada di lingkungan tempat penambangan tersebut. Hal inilah yang menyebabkan kegiatan penambangan seakan-akan memiliki daya tarik tersendiri, sehingga banyak penduduk yang 'mendekati' lokasi penambangan.

\subsection{Dampak Kerusakan Lingkungan yang Terjadi Akibat Penambangan Pasir di Kawasan Pegunungan}

Aktivitas penambangan sesungguhnya sudah dilakukan sejak zaman kerajaan, yang diawali dengan tanah liat sebagai bahan baku batu bata dan kemudian berkembang hingga penggalian pasir. Dunia pertambangan ahkirakhir ini sering di kecam sebagai penyebab "hancurnya" alam. Jika diperhatikan secara kasat mata, daerah-daerah yang memiliki potensi sumber daya yang melimpah, hal tersebut memang cenderung terjadi. Apalagi saat proses pemanfaatan berlangsung, tetapi yang perlu dicermati adalah kegiatan penambangan dilakukan oleh siapa, di mana proses tersebut dilakukan, dan kapan kegiatan tersebut dilakukan.

Penambangan pasir tidak hanya memberikan keuntungan dan manfaat tetapi juga menimbulkan permasalahan. Kegiatan penambangan pasir yang menggunakan alat berat yang berfungsi untuk mengeruk material yang berada di dataran maupun di dinding tebing menimbulkan permasalahan ekologis dan sosial bagi lingkungan sekitar. Dampak lingkungan dari kegiatan penambangan pasir di kawasan pegunungan dibedakan menjadi dua, yaitu dampak fisik dan dampak sosial ekonomi.

\section{Dampak Fisik Lingkungan}

Dampak fisik lingkungan dengan adanya kegiatan penambangan pasir di kawasan pegunungan (Yudhistira, dkk, 2011: 81) sebagai berikut:

a. Tingginya tingkat erosi di daerah penambangan pasir serta daerah sekitarnya. Tingginya erosi yang terjadi di lokasi penambangan pasir akan menyebabkan hanyutnya partikel-partikel tanah dan sangat berpengaruh terhadap struktur tanah. Struktur tanah remah akan berubah menjadi struktur polyder atau terlepas. Struktur tanah seperti ini menyebabkan rendahnya produktivitas hasil pertanian karena lahan tidak mengandung koloit tanah. Koloit tanah berfungsi sebagai perekat partikel-partikel tanah mendorong peningkatan stabilitas struktur tanah.

b. Adanya tebing-tebing yang tinggi rawan terjadi bahaya tanah longsor karena penambangan yang tidak memakai sistem berteras sehingga sudut lereng menjadi terjal dan mudah longsor. 
Potensi terjadinya longsor jelas sangat berbahaya baik bagi penambang maupun masyarakat yang berada di sekitarnya. Banyak dari pemilik tanah di sekitar lokasi penambangan karena takut terkena longsor terpaksa menjual tanahnya.

c. Penurunan kualitas air. Terjadinya penurunan kualitas air karena diakibatkan dari lahan yang telah menjadi terbuka karena tidak ada vegetasi penutup, sehingga air dapat mengalir dengan bebas. Debit air tanah juga akan menurun karena pepohonan yang dapat menampung air telah ikut ditebang dalam sistem penambangan pasir (dadan-muhamadramdan.blogspot.com).

d. Terjadi polusi udara. Kegiatan penambangan akan mengakibatkan terjadinya peningkatan debu yang menyebabkan kualitas udara disekitar daerah penambangan menurun akan menurun secara drastis, sebagai akibat dari kendaraan atau truk yang mengangkut pasir serta tiupan angin jika di lokasi penambangan tidak ada vegetasi yang cukup, karena telah ditebang.

e. Rusaknya jalan. Para penambang yang telah mendapatkan pasir biasanya menggunakan truk-truk pengangkut. Truk yang mengangkut pasir tersebut sudah tentu menggunakan alternatif jalan raya yang sudah pasti akan membuat jalan yang dilalui akan menjadi rusak dikarenakan berat beban pada kendaraan angkut tersebut melebihi kapasitas jalan yang ditentukan.

\section{Dampak Sosial Ekonomi Masyarakat}

Dampak sosial ekonomi yang dapat terjadi dengan adanya kegiatan penambangan pasir di kawasan pegunungan, adalah sebagai berikut:

a. Meningkatkan pendapatan masyarakat. Kegiatan penambangan pasir dapat meningkatkan pendapatan masyarakat, sehingga dapat memenuhi kebutuhan hidupnya.

b. Pengurangan jumlah pengangguran karena sebagian masyarakat bekerja menjadi tenaga kerja di penambangan pasir, baik sebagai pengawas, buruh tambang, penjual makanan dan minuman.

c. Membuka lapangan pekerjaan. Pada dasarnya tingkat ekonomi seseorang ditentukan oleh kesempatannya memperoleh pekerjaan, serta kesempatan untuk berusaha. Kesempatan kerja bagi masyarakat semakin terbuka lebar setelah adanya kegiatan penambangan pasir yang memberikan angin positif bagi warga sekitar sehingga dapat meningkatkan perekonomiannya.

d. Adanya pemasukan bagi pemilik tanah yang dijual atau disewakan untuk diambil pasirnya dengan harga tinggi. Tanah yang semula tidak menghasilkan menjadi bermanfaat karena dipakai untuk penambangan pasir. 
e. Banyaknya pendatang yang ikut menambang sehingga dapat menimbulkan konflik.

f. Adanya ketakutan sebagian masyarakat karena penambangan pasir yang berpotensi longsor sehingga sewaktu-waktu bisa mengenai lahan dan pemukiman mereka, apalagi bila turun hujan (Yudhistira, dkk, 2011: 81) .

\subsection{Tri Hita Karana dan Penambangan Pasir}

Lingkungan hidup merupakan satu kesatuan antara ruang dengan semua benda, daya, keadaan, dan makhluk hidup, termasuk di dalamnya manusia dan perilakunya, yang mempengaruhi kelangsungan kehidupan dan kesejahteraan manusia serta makhluk hidup lainnya. Dalam konteks ini juga menunjukkan bahwa agama mempunyai peranan yang sangat besar di dalam menjaga kelestarian lingkungan.

Agama telah menanamkan ajaran keharmonisan yang hendaknya senantiasa dijaga oleh umat guna mempertahankan lingkungan sehingga tetap terjaga dari kerusakan, sehingga akan tercapainya keseimbangan dalam kehidupan. Agar keseimbangan yang dimaksud dapat tercapai sesuai dengan harapan, maka setiap kegiatan yang melibatkan alam atau lingkungan hidup seperti penambangan pasir yang dilakukan di kawasan pegunungan hendaknya dilandasi dengan falsafah ajaran Tri

\section{Hita Karana.}

Secara etimologis istilah Tri Hita Karana berasal dari tiga kata yaitu Tri artinya tiga, Hita artinya harmonis, bahagia, dan Karana artinya penyebab. Jadi Tri Hita Karana adalah tiga penyebab kebahagiaan. Kebahagian akan terwujud apabila kita telah mampu mewujudkan suatu harmoni. Harmoni adalah suatu hubungan yang selaras dan seimbang antara manusia dengan Tuhan, manusia dengan sesamanya, dan manusia dengan lingkungan (Wiana, 2007: 5-6). Atas dasar pengertian keharmonisan inilah maka orang-orang Hindu tetap tidak mau memisahkan agama mereka dari kehidupan sehari-hari, atau untuk memisahkan kepercayaan dari kepercayaan besar lainnya di dunia.

Hubungan manusia dengan Tuhan (Parahyangan) lebih menekankan agar manusia menjaga kebersihan dan kesucian dirinya secara lahir dan bathin serta selalu mendekatkan diri pada beliau melalui tri sandhya, tirtayatra, yoga dan samadi. Hubungan manusia dengan sesamanya (Pawongan) hubungan ini melandasi rasa kasih sayang, saling menolong dan toleransi. Hubungan manusia dengan lingkungan (Palemahan) menekankan pada kemampuan manusia untuk memelihara, menjaga dan memperbaiki kualitas lingkungannya melalui serangkaian upacara tertentu (Oka, 2010: 45). Ketiga unsur itu, harus terjadi hubungan timbal balik yang harmonis dan serasi sehingga kesejahteraan dan kebahagiaan hidup akan tercapai.

Dasar filosofi dari Tri Hita Karana berdasarkan pada Bhagavad Gita III. 10 dimana unsur dari Tri Hita Karana adalah Prajapati, Praja, dan Kamadhuk. Filosofi hidup dalam 
Tri Hita Karana untuk mewujudkan sikap hidup seimbang dan konsisten untuk percaya dan bhakti pada Tuhan, mengabdi pada sesama dan memelihara kesejahtraan alam lingkungan. Pemahaman tentang Tri Hita Karana tidak boleh sepotong-sepotong karena itu hendaknya Tri Hita Karana di pahami sebagai suatu kesatuan yang utuh, sinergis dan konsisten sebagai filosofi hidup yang universal (Wiana, 2007: 8).

Nilai keseimbangan dan keharmonisan secara horizontal dan vertikal terefleksi dalam konsep Tri Hita Karana yakni keseimbangan secara horizontal dengan alam (palemahan) dan sesama manusia (pawongan) serta keseimbangan secara vertikal yaitu hubungan manusia dengan Tuhan (parahyangan). Konsep Tri Hita Karana tercermin dalam skala makro dan mikro dalam masyarakat Bali. Dalam skala makro, masyarakat bali memandang pulau Bali satu kesatuan mandala (palemahan), orang Bali sebagai satu kesatuan etnik bali (pawongan), dan pura merupakan sebagai satu kesatuan tempat suci.

Umat Hindu sangat mendambakan kerahayuan, keharmonisan dalam hidup, keseimbangan ekosistem, keseimbangan unsur-unsur yang membangun Bhuwana Alit dan Bhuwana Agung yang nanti pada gilirannya akan memberikan kerahayuan dan kedamaian. Menurut Sukabawa (2004: 121122), penerapan konsep Tri Hita Karana dapat terlihat dari pelaksanaan yajna yang dilakukan oleh masyarakat Hindu di Bali yaitu dalam pelaksanaan Upacara Tumpek Bubuh pada hari Saniscara Kliwon Wariga yang merupakan salah satu upaya atau usaha untuk melestarikan lingkungan. Upacara ini dalam rangka pemujaan kepada Tuhan dalam manifestasi-Nya sebagai Dewa Sangkara, dewanya tumbuh-tumbuhan. Upacara Tumpek Kandang pada hari Saniscara Kliwon Uye untuk menyatakan terima kasih kepada Tuhan dalam manifestasi-Nya sebagai Dewa Pasupati, pencipta binatang yang telah membantu pekerjaan manusia. Pada sistem padewasan masyarakat Bali juga ada petunjuk yang menyatakan bahwa tidak boleh menebang pohon bambu pada hari minggu, tidak boleh menebang kayu untuk bangunan apabila harinya berisi was, dan sebagainya.

\section{Parahyangan}

Konsep Tri Hita Karana merupakan konsep yang sangat baik dan mempunyai makna yang tinggi. Akan tetapi konsep ini sering tidak berjalan dengan baik disebabkan hubungan manusia dengan lingkungannya yang kurang harmonis. Alam akan memberikan hukuman kepada mereka yang menghilangkan sumber produksi alami seperti sawah, kebun, hutan dan sebagainya. Memenuhi segala keinginan yang tidak ada habisnya akan berakhir dengan berbagai masalah dan kesedihan. Begitu pula keserakahan manusia akan membawa mereka pada masalah yang semakin besar. Alam semesta adalah proses menuju keseimbangan. Mengingat manusia merupakan bagian dari alam, maka manusiapun sebenarnya menjadikan kesimbangan sebagai suatu cita-cita.

Manusiahanyamemikirkan, merencanakan dan melaksanakan berbagai ide dan gagasan dalam rangka peningkatan mutu kehidupan, 
sedangkan keberhasilannya sangat tergatung dari kehendak Tuhan (Ida Sang Hyang Widhi Wasa). Keyakinan umat Hindu ini menempatkan Hyang Widhi sebagai maha penentu kelangsungan dan kesuksesan hidup manusia di dunia.

Selain sebagai sumber pembangunan dan maha penentu, Tuhan merupakan sumber segalanya termasuk juga lingkungan yang merupakan perwujudan kasar dari Tuhan Yang Maha Esa. 'Pengerukan' sumber daya alam secara berlebihan tidak dibenarkan dalam agama Hindu, karena ajaran agama Hindu sangat menjunjung tinggi konsep bersahabat dengan alam semesta. Manusia dan juga alam semesta merupakan suatu kesatuan yang harus saling menjaga. Sebagaimana manusia sebagai makhluk hidup memiliki jiwa, alam semesta juga memiliki kesadaran, yaitu kesadaran kosmis. Hal ini dikarenakan alam semesta merupakan wujud nyata atau wujud kasar dari Tuhan Yang Maha Esa. Semua alam semesta diliputi oleh Tuhan Yang Maha Esa sebagaimana kutipan sloka Bhagavadgìtā XI. 7 berikut ini:

ihaika-stham jagat krṣtsnam

paśyādya sa-carācaram

mama dehe guḍeśa

yac cānyad draștum icchasi.

\section{Terjemahannya:}

Wahai Arjuna apapun yng ingin engkau lihat, lihatlah dengan segera dalam badan-Ku ini! Bentuk semesta ini dapat memperlihatkan kepadamu apapun yang engkau ingin lihat sekarang dan apapun yang engkau ingin lihat pada masa yang akan dating. Segala sesuatu baik yang bergerak maupun yang tidak bergerak berada di sini secara lengkap, di satu tempat (Prabhupada, 2006: 555).

Sesuai dengan kutipan di atas, mengeksploitasi alam semesta hingga membuatnya menjadi rusak akan sama artinya dengan kita merusak perwujudan Tuhan. Hal ini juga sama artinya dengan merusak tempat suci kita, bila itu terjadi maka bersembahyang dengan kusuk pun tidak akan dapat menghilangkan karma kita karena telah merusaknya.

\section{Pawongan}

Manusia disamping hidup bersama alam, manusia juga hidup bersama dengan sesamanya di dalam suatu sistem sosial. Sistem sosial tersebut sangat tergantung pada sistem budaya yang dianut oleh suatu masyarakat. Dalam sistem makrokosmos (Bhuana Agung) disebutkan bahwa unsur Tri Hita Karana itu meliputi jiwa alam (Brahman), manusia yang memiliki sabda, bayu, idep (suara, tenaga dan pikiran) sebagai penggerak atau pengelola alam dan fisik alam selaku tubuh kasar alam semesta (www. artayahonest.com).

Pawongan dalam konsep Tri Hita Karana boleh dikatakan merupakan perutnya keharmonisan, yang akan menggerakan dan mengelola kepala dan kaki. Kalau proses dalam perut itu berjalan secara positif maka kepala dan kakinya akan bergerak menuju ke arah positif juga. Kalau kita bawa kepada kehidupan maka apabila manusia sebagai pelaksana hubungan yang harmonis kepada Tuhan dan 
alam menjalakan hal-hal yang positif maka keharmonisan tersebut akan terwujud.

Uraian di atas merupakan suatu tatanan normatif yang seharusnya terjadi bila aspek pawongan dijalankan dengan baik. akan tetapi, seiring dengan perkembangan zaman setiap masyarakat pasti mengalami perubahan. Pada dasarnya, perubahan tersebut merupakan proses modifikasi struktur sosial dan pola budaya dalam suatu masyarakat. Perubahan yang terjadi dalam masyarakat disebut perubahan sosial, yaitu gejala umum yang terjadi sepanjang masa pada setiap masyarakat. Perubahan itu terjadi sesuai dengan hakikat dan sifat dasar manusia yang selalu ingin mengadakan perubahan. 'Kebosanan, manusia sebenarnya merupakan penyebab dari perubahan. Manusia selalu tidak puas dengan apa yang telah dicapainya. Ia selalu mencari sesuatu yang baru, bagaimana mengubah suatu keadaan agar lebih baik (Soekanto, 1983: 145).

Manusia merupakan makhluk yang selalu ingin berubah, aktif, kreatif, inovatif, agresif, selalu berkembang, dan responsif terhadap perubahan yang terjadi di masyarakat. Perbedaan perubahan antara masyarakat yang satu dan masyrakat yang lain atau antara kurun waktu yang satu dan kurun waktu lainnya hanyalah terletak pada tingkat kecepatan perubahan tersebut. Perubahan yang terjadi di masyarakat meliputi perubahan norma-norma sosial, interaksi sosial, pola-pola perilaku, organisasi sosial, lembaga kemasyarakatan, lapisan-lapisan masyarakat, serta susunan kekuasaan dan wewenang.

Hal tersebut juga terjadi pada masyarakat di kawasan pegunungan. Sekarang ini masyarakat di sekitar sana telah mengubah motivasinya dalam memanfaatkan sumber daya alam agar dapat memperoleh keuntungan yang sangat berlimpah atau dengan kata lain masyarakat kini telah mengubah ideologi dari bersahabat dengan lingkungan menjadi "penakluk" lingkungan demi keuntungan pribadi. Permintaan yang tinggi terhadap pasir serta berubahnya ideologi masyarakat mengakibatkan kegiatan eksploitasi itu semakin menjadi-jadi, kini dampak kerusakan lingkungan tidak lagi menjadi suatu ketakutan bagi mereka, semuanya diabaikan demi gelimangan uang.

Faktor geografis serta ideologi merubah kehidupan masyarakat sebagaimana yang dinyatakan oleh John Lewis Gillin dan John Philip Gillin dalam teori perubahan sosialnya, mereka melihat perubahan sosial sebagai suatu variasi dari cara-cara hidup yang telah diterima baik karena perubahan kondisi geografis, kebudayaan material, komposisi penduduk, ideologi maupun karena adanya difusi ataupun penemuan-penemuan baru dalam masyarakat (Ruswanto, 2004: 63).

\section{Palemahan}

Tri Hita Karana pada hakekatnya adalah sikap hidup yang seimbang antara memuja Hyang Widhi dengan mengabdi pada sesama manusia serta mengembangkan kasih sayang pada alam lingkungan. Hubungkan ini bukan merupakan hal yang terpisah-pisah. Dengan kata lain hubungan itu harus menyatu membentuk sikap hidup dalam konsep Tri Hita Karana.

Berbagai upaya-upaya telah dilakukan yang dilandasi oleh faktor-faktor pendorong untuk 
menerapkan konsep Tri Hita Karana dalam pengelolaan lingkungan hidup di lokasi penambangan pasir yang hendaknya dilaksanakan agar kerusakan lingkungan yang diakibatkan dari adanya penambangan tersebut tidak berlarut-larut terjadi. Apabila ajaran Tri Hita Karana, khususnya pada bagian palemahan tak juga kunjung dilaksanakan atau diimplementasikan di wilayah kawasan penambangan, maka akan menimbulkan berbagai dampak yang akan terjadi, diantaranya adalah:

a. Lingkungan desa bersangkutan akan menjadi kering.

b. Hutan atau vegetasi disekitar daerah penambangan akan menjadi rusak.

c. Bahaya tanah longsor akan menjadi ancaman bagi masyarakat sekitarnya.

d. Menipisnya sumber-sumber mata air yang dapat dimanfaatkan warga.

Oleh sebab itu masyarakat setempat di daerah penambangan pasir haruslah menyadari bahwa kewajiban utama kelahiran manusia adalah memelihara ciptaan Tuhan yang lainnya, yaitu alam semesta/lingkungan sebagaimana yang tersurat dalam Manava Dharmasastra I. 87:

sarvasyāsya tu sargasya

guptyarthai் sa mahādyutiḥ, mukhabāhūr upajjānām

prthak karmānya kalpayat.

Terjemahannya:

Untuk melindungi semua ciptaan-Nya ini, Yang Maha Cemerlang menetapkan setiap kewajiban yang berbeda-beda seperti halnya mulut, lengan, paha, dan kaki (Pudja dan Sudharta, 2004: 21).

Kutipan sloka di atas mengisyaratkan tugas manusia sebagai pelindung dari ciptaan Tuhan yang lainnya, yaitu alam semesta beserta isinya. Selanjutnya Donder (2007: 215-216) menyatakan bahwa yang patut disadari oleh setiap manusia adalah bahwa setiap manusia selain memiliki tubuh fisik ia juga memiliki Utma. Manusia juga dilahirkan di dunia ini dengan wajah menyerupai wajah deva, sehingga manusia disebut citra devata (gambaran Tuhan), adalah terkait dengan mandat yang diberikan Tuhan untuk memelihara dunia.

Alam semesta/lingkungan tentu harus dipelihara karena manusia tidak bisa lepas dari keberadaan alam semesta. Manusia tidak boleh hanya memandang sisi untuk memanfaatkan lingkunga sebagai tempat tinggal dan sebagai sumber kehidupan, akan tetapi harus selalu diingat bahwa manusia juga diciptakan untuk menjaga lingkungannya, sehingga di daerah pegunungan yang memiliki sumber daya alam seperti pasir yang melimpah haruslah mengambil sikap bijak dalam memanfaatkan sumber daya alam tersebut.

Gunung merupakan salah satu potensi alam/ potensi kekayaan yang ada di lingkungan kita. Gunung juga merupakan tempat suci bagi umat Hindu, karena gunung merupakan tempat bersthananya Tuhan Yang Maha Esa, sehingga pegunungan wajib mendapatkan pemeliharaan dari manusia, misalnya dijaga kelestariannya. Lebih jauh mengenai gunung sebagai tempat suci diuraikan dalam Tantra Samuccaya I.1.28 
yaitu:

"Para dewa tidak hanya berkenan untuk turun dan tinggal di tirtha (Patīrthan), di tepi sungai, dan danau, tetapi juga tepi pantai pertemuan dua atau lebih sungai-sungai, dan kuala (muara sungai), di puncak-puncak gunung atau bukit-bukit, di lereng-lereng pegunungan, di hutan, di semak belukar dan kebun atau tamantaman, dekat tempat-tempat yang dirahmati atau pertapaan, di desa-desa, kota-kota dan di tempat-tempat lai yang membahagiakan" (Titib, 2003: 87).

Selain dianggap suci, memang sudah dinyatakan pula dalam kitab suci bahwa gunung memiliki keindahan dan juga menyimpan kekayaan, sebagaimana yang tersurat dalam mantra Rgveda I. 130.3:

\section{Guhā nidhim-parivitam aśmani anante}

Artinya:

Pengunungan-pegunungan mengandung harta benda di dalamnya (Titib, 1996: 682).

Akan tetapi kekayaan yang ada di alam harus dimanfaatkan dengan cara yang jujur dan juga saleh serta penuh etika karena hanya harta yang diperoleh dengan kejujuran sajalah yang membawa keberuntungan pada hidup kita. Mengenai cara memperoleh kekayaan dengan jujur terdapat dalam mantra Igveda I. 132.2 berikut:

\section{Bhadrā bhadrasya rātayah}

Artinya:
Kemakmuran orang yang saleh selalu menguntungkan dan mantap (Titib, 1996: 572).

Berdasarkan uraian di atas kita ketahui gunung merupakan tempat suci dalam Agama Hindu, gunung juga menyimpan banyak kekayaan yang bisa digunakan oleh manusia untuk mempertahankan hidup, akan tetapi dalam memanfaatkan sumber daya alam pegunungan haruslah dilakukan dengan sikap yang bijak dengan kajian yang matang, agar daerah pegunungan yang kita sucikan tidak rusak dan menimbulkan suatu bencana.

\section{PENUTUP}

\subsection{Simpulan}

Dampak kerusakan lingkungan dari kegiatan penambangan pasir di kawasan pegunungan dapat dibedakan menjadi dua, yaitu dampak fisik dan dampak sosial ekonomi.

Hubungan manusia dengan Tuhan (Parahyangan) lebih menekankan agar manusia menjaga kebersihan dan kesucian dirinya secara lahir dan bathin serta selalu mendekatkan diri pada Beliau. Hubungan manusia dengan sesamanya (Pawongan), hubungan ini melandasi rasa kasih sayang, saling menolong dan toleransi. Hubungan manusia dengan lingkungan (Palemahan) menekankan pada kemampuan manusia untuk memelihara, menjaga dan memperbaiki kualitas lingkungannya. Ketiga unsur itu, harus terjadi hubungan timbal balik yang harmonis dan serasi sehingga kesejahteraan dan kebahagiaan hidup akan tercapai. 


\section{DAFTAR PUSTAKA}

Donder, I Ketut. 2007. Kosmologi Hindu. Surabaya: Paramita.

Oka, I Dewa Gde Rai. 2010. Kebenaran Abadi pengenalan Dasar Agama Hindu. Yayasan Dewi Saraswati: Mataram.

Prabhupada, Svami. 2006. Bhagavadgita menurut Aslinya. Alih Bahasa oleh Tim Penerjemah. Jakarta: Hanuman Sakti.

Pudja, G. dan Tjokorda Rai Sudharta. 2004. Mānava Dharmaśastra. Surabaya: Paramita.

Ruswanto. 2004. Buku Materi Pokok Perubahan Sosial. Jakarta: Universitas Terbuka.

Setia, Putu. Desember 2006. Tri Hita Karana. Raditya.

Soekanto, Soerjono. 1983. Teori Sosiologi Tentang Perubahan Sosial. Jakarta: Ghalia Indonesia.

Soemarwoto, Otto. 2003. Analisis Mengenai Dampak Lingkungan. Gadjah Mada University Press: Yogyakarta.

Sukabawa, I Wayan. 2004. “Upacara Wana Kerti di Hutan Batukaru, Desa Wongaya Gede, Analisis Bentuk, Fungsi, Makna". Tesis Program Pascasarjana Institut Hindu Dharma Negeri (IHDN) Denpasar.

Titib, I Made. 1996. Veda Sabda Suci Pedoman Praktis Kehidupan. Surabaya: Paramita.

Titib, I Made. 2003. Teologi dan Simbol-simbol dalam Agama Hindu. Surabaya: Paramita.
Titib, I Made. 2010. "Pelestarian Lingkungan: Perspektif Agama Hindu". Makalah disampaikan pada acara Seminar bertema: "Melalui Partisipasi Aktif Masyarakat Kita Tingkatkan Kualitas Sumber Daya Manusia dan Kualitas Lingkungan" diselenggarakan oleh Desa Pakraman Kubu, Kelurahan Kubu, Kecamatan Kota dan Kabupaten Bangli.

Wiana, I Ketut. 2004. Pelestarian Lingkungan Hidup Menurut Konsep Hindu. Jurnal Widya Darma Sastra.

Wiana, I Ketut. 2007. Tri Hita Karana Menurut Konsep Hindu. Paramita: Surabaya.

Yudhistira, Wahyu Krisna Hidayat, Agus Hadiyarto. 2011. Kajian Dampak Kerusakan Lingkungan Akibat Kegiatan Penambangan Pasir di Desa Keningar Daerah Kawasan Gunung Merapi. Jurnal Ilmu Lingkungan, Volume 9 (2).

Dadan-muhamad-ramdan.blogspot.com/2011/06/ abstrak-mempunyai-latar.html?m=1

http://www.artayahonest.com/2012/09/tri-hitakarana-lingkungan.html\#.VFmR2ZTuCSo 